Journal

of Geography

Politics and Society

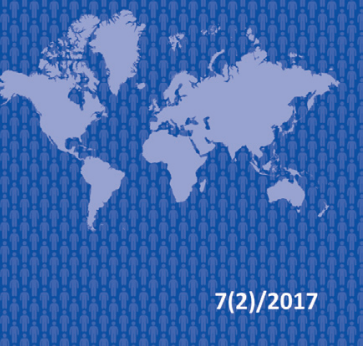

\section{Journal of Geography, Politics and Society}

$2017,7(2), 48-63$

DOI 10.4467/24512249JG.17.015.6631

\title{
HUMAN AND GEOGRAPHICAL ANALYSIS OF HISTORICAL AND CULTURAL HERITAGE OF LVIV
}

\author{
Oleh Shabliy \\ Faculty of Geography, Ivan Franko National University of Lviv, Doroshenka, 41, 79000 Lviv, Ukraine, \\ e-mail: shabliy@franko.Iviv.ua
}

\section{Citation}

Shabliy O., 2017, Human and geographical analysis of historical and cultural heritage of Lviv, Journal of Geography, Politics and Society, 7(2) 48-63.

\begin{abstract}
This article contains the authors' understanding of "cultural heritage" that is substantiated as the object of interdisciplinary research, and place of human geography in it. In addition, the features of interdisciplinary discourse in this object research are regarded. The input of English speaking (USA, UK) and Ukrainian scientists to defining place of geography of culture at the human geography is enlighten. Special attention is paid to historical culture genesis in big core of culture - Lviv city and up-today geospatial organization of geocultural artifacts, objects, form of accumulation and places of its concentration.
\end{abstract}

\section{Key words}

Lviv, culture, cultural heritage, geospatial organization, geographical places, combination of objects of cultural heritage.

\section{Introduction}

The key word in the issue of "historical and cultural heritage" is the term and concept of culture. It is extremely complex and has many meanings. In research of culture, it appears that the number of meanings is over 500. It is clear that the concept of culture is of interdisciplinary nature. So it is studied by, at least, humanities, social sciences, including primarily philosophy, sociology, cultural studies, history, psychology and others. The most common and fundamental definitions are given by philosophy. We are primarily interested in geographical aspects of culture, particularly cultural heritage on the one hand, and the issue of geography of culture in the context of human and nature geography.
The concept of culture is most fully studied by philosophical science and cultural studies. According to the encyclopedic dictionary "Cultural Studies" (Культурологія..., 2013) edited by prof. V. Melnyk, "culture (lat. colo, colare - to grow something, process, care, nurture, bring to perfection) - 1) key concept of cultural studies [...]. The culture is understood as a certain set of important for people symbols, ideas, values, beliefs, norms, traditions that are acquired by a human as a member of society, are passed on from generation to generation and with the help of which organization of human activity takes place...; 2) culture is a complex, integrated and coherent social and historical phenomenon of creation by a human and society of an own world, different from the world of nature, the world of "second nature" - the 
world filled with human sense ..." (Культурологія..., 2013, p. 199).

The authors of cultural studies encyclopedia single out three main modern approaches to understanding of culture: anthropological, social and philosophical.

Anthropological understanding stems from recognition of a single "anthropological basis" of culture, which conditions equivalence of cultures of all people of the world, and defines the very culture as a vital need and way of human existence. Sociologi$\mathrm{cal}$ disclosure of culture equates it with certain most developed sides and manifestations of material and spiritual life of people and life activities of society (such as culture of work, life, ecological culture, etc.).

Philosophical understanding of culture is connected with the highest abstraction and the most general definition which is close to the concept of "civilization". In fact, the above mentioned definition of culture (as a set of important for people symbols, ideas, values, etc.) is the philosophical understanding of it (Культурологія..., 2013, p. 199-200).

One should not avoid in a complex system of culture such a concept as "subculture". According to the encyclopedic dictionary, subculture is "a culture of certain communities, groups within a dominant or a broader in scope and subject culture; a set of symbols, ideas, beliefs, values, norms, ideals, behavior stereotypes, style of dress, manners, etc., resulting from the transformation of a respective system of traditional culture" (Культурологія..., 2013, р. 390). Examples of subcultures are: the subcultures of goths, punks, hippies, skinheads and others. In Lviv, in the interwar period, the subculture of the so-called batiars ${ }^{1}$ with their special folklore, slang, behavior, etc., existed. After the war, it almost completely disappeared or transferred with its bearers to the western lands of present-day Poland. Currently in Lviv, only statutory "holiday" of batiars on the first of May recalls it. At the same time, dictionaries of Lviv "street language" ("Ivivska hovirka"), songs and several elements of this original type of subculture were published.

But we are primarily interested in the category of "cultural heritage". Here the emphasis shifts to a large extent in the sphere of law. Whereas, not only the rights of an individual, but also of human communities (e.g., nation), associations, territorial

\footnotetext{
1 Batiar (also sometimes spelled as baciar), a popular name for a certain class of inhabitants of the formerly Polish city of Lwów (present Ukraine, Lviv). It used to be a part of the city's subculture, Lviv's "knajpa" lifestyle, and became a phenomenon at the beginning of the twentieth century although its roots go back to the mid nineteenth century.
}

communities. This question is related to continuity of an individual or collective owner, to its continuum of possession of cultural heritage in time and space.

In this context, the concept of historical and cultural heritage appears. That is how the cultural studies encyclopedia defines the concept: "cultural heritage is the total of all cultural achievements (material and spiritual) of a society, its historical experience, which is stored in arsenal of social memory. Cultural heritage is particularly valuable because it contains different achievements of different time ranges, which move to new generations in new epochs" (Культурологія..., 2013, р. 208).

Note certain features of our understanding of historical and cultural heritage $(\mathrm{HCH})$.

Firstly, this concept is studied mainly in cultural and historical sciences. In addition, jurisprudence and human geography are taking a prominent place now. Consequently, the concept is interdisciplinary by its definition. In human geography (previously - anthropogeography), the issue of historical and cultural heritage is not even raised. Although, the founder of modern Ukrainian geography, academician S. Rudnytsky (Рудницький, 1905) in his classification of sciences, particularly in anthropogeography along with human geography, economic geography and political geography, also singles out geography of culture.

Secondly, historical and cultural heritage should be interpreted as spiritual and (or) material values, produced in the past, accepted by society as a whole or by its individual subsystems (nation, class, social stratum, territorial community, etc.), perceived and used in their primary historical entity (especially, according to functions), or have only applied value, or used for knowledge of the past. Their historicity lies primarily in the fact that they, in their development and existence, cover a significant period of time, retained their entity as an important marker of territory (region, country, nation, state, etc.) and keep potential, gained in the previous epochs for traditional or new uses (consumption) as cognitive, including aesthetic resource. We consider historical and cultural heritage mainly in this second meaning of it.

Thirdly, whole historical and cultural heritage is divided into two major groups: spiritual and material. Some of the representatives of each group are simultaneously both spiritual and material heritage. At least by the fact that spiritual values in most cases have their material media. Moreover, spiritual heritage has more opportunities to change its location in space and time than material values.

Each of these two clusters of historical and cultural heritage - spiritual and material, has its internal structure. It is represented by many groups, types 
and forms of historical and cultural heritage. For example, spiritual heritage covers artistic and scientific (including scientific popular), religious and educational and pedagogical literature, visual and applied arts, architecture and sculpture. The latter two types are simultaneously separate representatives of material heritage. As well as production equipment and technology of production sphere: agricultural, industrial, construction, transport, etc. Therefore, all former enterprises without exception - producers of goods and institutions of service provision, including material, such as home repairs, tailoring - sewing workshops, traces of which are remained by archaeological layers, etc., we include in historical and cultural heritage.

\section{Fundamental problems of geographical research of historical and cultural heritage}

Two fundamental problems that arose and were not fully resolved in cultural studies and geography of historical and cultural heritage are influence of the natural environment on historical and cultural heritage and the problem of the role of national factor in "appropriation" of this heritage.

The first problem is influence of natural environment on emergence and development of elements (objects) of historical and cultural heritage, their geospatial combinations and systems. The majority of scholars are of the opinion that natural phenomena themselves and their geographical distribution or combination are not components of historical and cultural heritage. It is clear why: because they have natural, not social origins.

But this view is very categorical. Because in fact there is no natural object (phenomenon, process), which would not have experienced a certain impact of social activity. That means that it is humanized. At least because it was studied by a relevant scientific discipline or covered by practice activities and fixed in space with certain marks, implements, legal acts, etc. In this context, in the early twentieth century german scientist O. Schluter and later E. Neef (Heeф, 1974) introduced the concept "cultural landscape".

Take for example the Main European Watershed (MEW), the line of which passes through the territory of the city of Lviv. This is a natural "object", to be more exact, it is geometric locus of points, which are not always the highest on hypsometric map and embroidered with lines of streets and residential development. What is "historical" and "cultural" actually here?

The fact is that the Main European Watershed may be a potential object of educational tourism, if it is appropriately "publicly" equipped: to make touristic schematic maps, and mark on them and record the highest and lowest places, bring them to trails or streets, build items of tourism leaflets realization, badges, organize fast food items, etc. Consequently, the Lviv fragment of the Main European Watershed becomes an object of historical and cultural heritage, which has a natural basis and social content load.

National identification of historical and cultural heritage is a somewhat more complicated problem than the previous one. The easiest solution in our time would be according to the principle: cultural heritage belongs to the state (Germany, Poland, Ukraine, etc.) on the territory of which it is located. If one considers that the principle of herderism (from the name of German scientist J.G. Herder (17441803)) passes into history, and in each state, one political nation is forming, then all cultural achievements of the past on the territory of that state are property of all its citizens, regardless of their ethnic origin.

Finally, the so-called principle of finalism can be introduced for national identification of cultural and historical heritage: investment of ethnoses (subethnoses, ethnic groups, etc.) of the past in cultural heritage of national (or state) territory. Thus, in Lviv, construction of many buildings was financed by immigrants from Greece, Italy, Poland in particular and other countries (temples, palaces, public buildings, memorials, etc.). Thus, from the standpoint of economic nationalism, they would belong to historical and cultural heritage of respective nations. They were designed, planned and generally artfully decorated by outlandish invited architects, painters, sculptors, etc. By this time, it is unknown of which origin brilliant sculptor of Baroque epoch Johann Pinsel, who created masterpieces of world importance, was. They remain to be property of the Ukrainian state as an "investment" of the past, invested in Ukrainian national heritage.

Two or three methods of soft solution to the conflicts that arise in the field of interpretation of national identity of objects and phenomena of historical and cultural heritage can also be suggested:

a) not to provide them with political overtones. An example would be the monument to outstanding Polish poet of Romanticism epoch Adam Mickiewicz in Lviv. Built in the early XX century upon the project of Polish (A. Poppel) and Ukrainian (M. Parashchak) sculptors, it even moved the statue of the Virgin Mary to just 20 meters from its place, but did not cause any confrontation neither between Poles and Ukrainians, nor between the religious and atheists, nor between the government (Austrian) and society; 
b) for government and cultural elite to interpret objects (phenomena, processes) of historical and cultural heritage as nationally dualistic or trialistic, even when historically they were confrontational in inter-ethnic relations, by introducing joint celebrations of their anniversaries and dates through mutual apology and repentance, joint memorials (examples of this approach are already numerous enough in the area of UkrainianPolish borderlands).

In the Western world, problems of research of historical and cultural heritage and its geographical aspects have a long tradition. At least the intensity of this process is observed especially in the postwar years, particularly in the English-speaking world, especially in the USA and Great Britain. Here journals "Annals of the Association of American Geographers", "International Journal of Heritage Studies", "Journal of Heritage Tourism", "International Journal of Heritage Studies" and others are issued.

Among Western scholars, greatest success have researchers: K. Brown (2009), D. Harvey $(1979,2015)$, D. Hobsbawm and T. Ranger (2001), D. Knudsen and C.E. Greer (2008), D. Lowenthal (2005), P.H. Meserve (The National Geographic..., 1999) and others. English-language resources of these and other authors highlight new aspects of understanding of historical and cultural heritage mainly in line with development of post-industrial society and post-modern discourse.

American geographers believe that "culture provides the identity that links members of one society together and can also divide those members from other cultures. Cultural geography analyzes the spatial context of these cultural processeswhere cultures originate, how they diffuse over Earth, what regional identities are created, and what conflicts arise between cultural groups. Despite the increasing globalization of popular culture, there is no world culture yet, and regional differences remain extremely important for understanding how the world works. Increased economic and political ties between cultures will, however, help to increase mutual appreciation of different cultures and reduce the risk of future conflicts" (The National Geographic..., 1999, p. 316). At the same time, P.H. Meserve gives the following definition to region of culture in the context of the concept of landscape: "Cultural regions is a general term for areas where some portion of the population shares some degree of cultural identity. How and by whom cultural regions are defined determines the nature' of the region and its extent and boundaries. In some cases a single criterion will suffice because it is linked to so many other traits" (The National Geographic..., 1999, p. 295).

In American special literature, we have not found any sources of geography of historical and cultural heritage of large cities.

The first among Ukrainian scientists to identify the geography of culture in the branch structure of anthropogeography (without emphasis on cultural heritage), was academician S. Rudnytsky (Рудницький, 1905). After his annihilation by the Bolshevik regime (1937), no one touched upon the problems of this component of anthropogeography in the USSR. Only in 1934, scientists timidly introduce in economic geography a human in the role of labor force as a factor of development and location of production.

Large research of geography of culture - monograph (Ровенчак, 2008) entitled: "The Geography of Culture: Problems of Theory, Methodology and Research Methods" and defense of doctoral thesis was conducted at the Department of economic and social geography by associate professor I. Rovenchak (Ровенчак, 2008) under our guidance. A modern Ukrainian theory of geography of culture was developed for the first time.

\section{The phenomenon of Lviv and its cultural heritage}

Lviv is the cultural capital of Ukraine. It is an old city, which appeared in 1256 (first annalistic mention). According to new data (Паславський, 2010), Lviv was founded in 1240. In my opinion, as expressed in the book "Academician Stepan Rudnytsky" (Шаблій, 1993), Danylo Halytskyi (Daniel of Galicia) after burning of Zvenihorod by Batu Khan (in $25 \mathrm{~km}$ south-eastward from present-day Lviv) came to the conclusion that the location of this defense center of homonymous land is inappropriate. Therefore, he chose a new defense center on the rough terrain in the upper reaches of the Poltva River, naming it in honor of his son Lev (Leo).

A lot of factual material on geography of culture and historical and cultural heritage of Lviv can be gleaned from the works of Ukrainian and Polish scientists and travelers: M. Bałaban (1909), M. Gruneweg (Груневеґ, 1980), М. Dołynska (Долинська, 2006) Ya. Zapasko, O. Maciuk, W. Stasenko (Запаско et al., 2000), B. Zymorowicz (Зиморович, 2002), Ya. Isayewich (Ісаєвич (ed.), 2005), B. Janush (1918), M. Kapral (Капраль, 2003), I. Kachor, L. Kachor (Качop, Качоp, 2009), W. Łoziński (1901), I. Melnyk (Мельник, 2008), O. Stepaniv (Степанів, 1943), L. Charewiczowa (1925) and others. 
Lviv is a special phenomenon on historical and cultural map of Ukraine and Europe as a whole. Primarily, its geographical and civilizational macro location is specific.

First. Being located in Eastern Europe, it also belongs to the Western cultural circle (Маланюк, 1992). This view stems from the premise of M. Hrushevskyi, that "historical conditions of life oriented [Ukraine] towards West, geographically oriented and orient southward, towards the Black Sea..." (Грушевський, 1991, p. 23). At the same time, Ukraine and Lviv performed a transmitting civilization function in Eastern Europe. Many immigrants from Ukraine, including those from Lviv (F. Prokopovych, S. Yavorskyi, P. Ratskyi, Ya. Markovych et al.) for some time, especially in XVII-XVIII centuries, worked in religious and educational and enlightenment system of Muscovy.

Second. The phenomenon of Lviv lies in its specific natural and geographical location. It is located on the Major European Intersection. In particular, it is located in the middle of the Main European Watershed (MEW) in the place of its intersection with the shortest line between the Baltic (Gdańsk) and the Black (Odessa) sea. This is a unique phenomenon: distance from Lviv to Odessa and to Gdańsk is almost the same - approximately $600 \mathrm{~km}$. This location of the only major city in the center hubs of Main European Watershed and the Baltic and the Black Sea area some call Genius Loci - Localization of genius. Figuratively speaking, "Lviv - on the cross or the cross on Lviv?".

Third. From its origin up to modern times, Lviv, if not explicitly, then latently, performed metropolitans functions in Halychyna (Galicia), the Kingdom of Galicia-Volhynia or even in Ukraine. That is, it accumulated its state experience and heritage, both at regional and at national levels.

Fourth. It is in Lviv, unique cultural and historical events, processes and their outstanding representatives manifested and fixated themselves. Due to this, spiritual and cultural field of Lviv extends far outside Halychyna (Galicia). It is mainly nationwide. In many ways, Lviv is a pioneer. It is in Lviv, the first "Bukvar" (school primer) was printed and the Orthodox Brotherhood of citizens was organized (1586), a university of European type was founded (1661), the first newspaper was published (1776), uncrowned (informal, pro bono) Academy of Sciences of Ukraine - Shevchenko Scientific Society was created (1873), foreign members of which were A. Einstein, Max Planck, V. Vernadsky and others. Lviv is the first political party in Ukraine (1890), the first railway, pharmacy, post office, theater, bank, gas-lamp, coffee house, even a football match and many more "firsts". The highest spokesmen of spirit - representants of
Lviv and the entire Ukraine - were writer Ivan Franko and Metropolitan Andrey Sheptytsky.

Fifth. From the very beginning, Lviv had been developing as an important center at the intersection of trade and economic, and national and cultural traverses. Exept Ukrainians and Poles, Germans, Armenians, Hebrews, Tatars, Greeks, Italians, Hungarians and other ethnic minorities, side by side, lived here and shared achievements of culture and technology. In the XX century, Russians and members of other ethnic groups of the Soviet Union added. In Lviv, there never were (except military time) any bloody inter-ethnic conflicts. Interchange of cultural values distinguishes Lviv among macropolises, especially of metropolitan type on the map of Europe.

Finally, the sixth. Although, in Lviv, there has never been ethnic and cultural segregation, sometimes certain localization of representatives of certain ethnic groups, and social and religious denomination identity has been observed. Thus, since medieval times, some districts were occupied by Jews, Armenians and Tatars. Later, in the city center (within the walls), on specific streets with their religious centers concentrated: Ukrainians (Rus'ka St.), Poles (Krakivska St.), Armenians (Virmenska St.), Jews (Zhydivska St.), Tatars (Kraków suburb) and others.

Social and spatial differentiation was especially evident after 30s of the XIX century, when the city center walls were removed. Then, especially Kraków, Halytske (Galician), Lychakiv and Zhovkva suburbs looked like abandoned Rusyn-Jewish, almost not regulated, similar to South American bungalow, districts.

It was exactly beyond them, in different directions, at the end of the Austrian period and especially in the interwar years, along radial streets, districts with luxurious and not very ones, but architecturally modern villas, grew. These streets and districts are Yevhen Konovalets St., Acad. Serhiy Yefremov St., General Chuprynka St., Kotliarevskyi St., Kastelivka St., Nebesnoi Sotni St., Snopkivska St., Pasichna St., Lychakivska St., Lysenko St., Sichovykh Striltsiv St., Lystopadovoho Chynu St., Shevchenko Prosp. and others.

And in Soviet time, a large belt of housing development grew, where mainly comers from the surrounding rural areas concentrated. This belt of the so-called Khrushchyovkas - four- or nine-storey uncomfortable for life buildings with not-so-great range of services - trade, domestic, educational and cultural. Only except religious. It is now, new churches mostly of Greek Catholic confession are built in the outlying area. Exactly here in 2001, during his visit to Ukraine, Pope John Paul II consecrated a temple. 


\section{Historical and cultural gradation of Lviv}

The first historical and cultural gradation of Lviv was carried out in the XVI century by original Lviv poet and chronicler Józef Bartłomiej Zimorowic (Зиморович, 2002) in the book "Leopolis triplex" ("Triple Lviv"). He divided history and culture of Lviv into three periods: Ruthenian (Ukrainian), German and Polish.

Ruthenian Lviv - from origin of the city to the death of Prince Leo (Knyaz Lev) (c.1301). This is about foundation of the city and ethnic groups that inhabited Lviv, its building (walls and castles), the story of the icon of the Virgin Mary - patroness of Lviv (later icon of Our Lady of Częstochowa). J.B. Zimorowic back, in the XVI century was intolerant towards ethnic groups and their cultures - Rusyns, Jews, Tatars, Armenians, who lived there during that time. This is especially true in regard to their customs and way of life.

German Lviv - a short time before the final occupation of Lviv by Queen Jadwiga of Poland (in 1387). During this period, appear the following features of culture of Germanic peoples: city government (in infrastructure - a town hall with a surrounding market, quadratic square and rectangular layout of streets from it to external walls (towers, basteis, loopholes in the walls). It had already been European culture of construction and defense of city. In Lviv, appear Catholic religious orders and churches (Dominicans, Franciscans and others.), leading to the formation of multiculturalism and spatial mosaics of the city.

Lviv became Polish since 1387, when it was ultimately under the rule of the Kingdom of Poland. Until 1551, that is good hundred sixty some odd years - it had been transition from German to actually Polish period. The ending date of this period was the fire of Lviv in 1527. Then, gothic Lviv was completely burned. In Lviv, during the transition period, there were many "cultural" features of German: management of the city (it was since 1356 when Lviv received Magdeburg rights as a legal basis for its self-government and self-development). Armenian and German population were gradually polonized. Armenians brought here the culture of vine (plantations on the southern slopes of Kaiserwald) and wine production. In Lviv, craft and trade culture are rapidly developed (workshop organization, trade guilds and corporations, etc.).

The second subperiod of Polish Lviv stretched from 1551 until the start of the war of Bohdan Khmelnytsky in 1648 , that is about a hundred years. (see Fig. 1). In historical and cultural terms, it was characterized by the struggle of Catholicism and Orthodoxy, which led to creation of the Uniate Church
(1596). However, the union was accepted in Lviv only in the early XVIII century, that is in 105 years after its signing in Brest. Although, in the ritual culture of the Orthodoxy and Greek Catholicism, there is no special distinction.

At the same time, the Orthodox Church, culture and education had little changed. The organized Orthodoxy developed different forms of self-defense and further development: brotherhoods of citizens, development of education and book printing, construction. No wonder printer I. Fedorovych came here from Zabłudów in Podlasie to "to revive the forgotten art of printing".

The third Polish subperiod is also can be talked about (1648-1772). This subperiod conditionally ends when Lviv and Halychyna (Galicia) became part of the Austrian monarchy. The new period can be called Austrian or quasi-German. It stretched chronologically until 1918, which is almost 150 years and left an imprint on the culture of Lviv and on its entire historical and cultural heritage.

Particularly, it is:

a) redevelopment of the city after the fashion of European metropolises: removal of ramparts and defensive walls and construction of boulevards on them, formation of centrifugal radial roads: consequently, planning and spatial organization of the city significantly changed towards modernization (except the Rynok (Market) Square and its environment);

b) cultural and spiritual revolution took place: Lviv firmly established (since 1784) as a university center of Eastern Europe, Kraków competitor. Religious sphere became of European character (organization of Maria Theresa sponsored secondary school, preparing Greek Catholic priests, which later - in 1929, was transformed by Metropolitan Andrey Sheptytsky into a high-educational Greek Catholic Academy. Scientific sphere enriched with a modern "uncrowned Academy" - Shevchenko Scientific Society (1873), which was headed in 1893 by distinguished historian M. Hrushevsky (1867-1934). Then, in the university, in 1882, the Department of Geography was organized for the first time with its chair prof. A. Rehman (1840-1917). His first educatee, PhD became in 1893 Ukrainian H. Velychko (1863-1932);

c) there was a radical change in the architecture of Lviv. Exactly from this time, especially in the middle of the XIX century, modern architectural image of Lviv had formed. Here, the new European style wholly established Baroque and Rococo at first (especially in the construction and reconstruction of the temple buildings (Dominican church, Bernardine church, Latin Cathedral, St. 

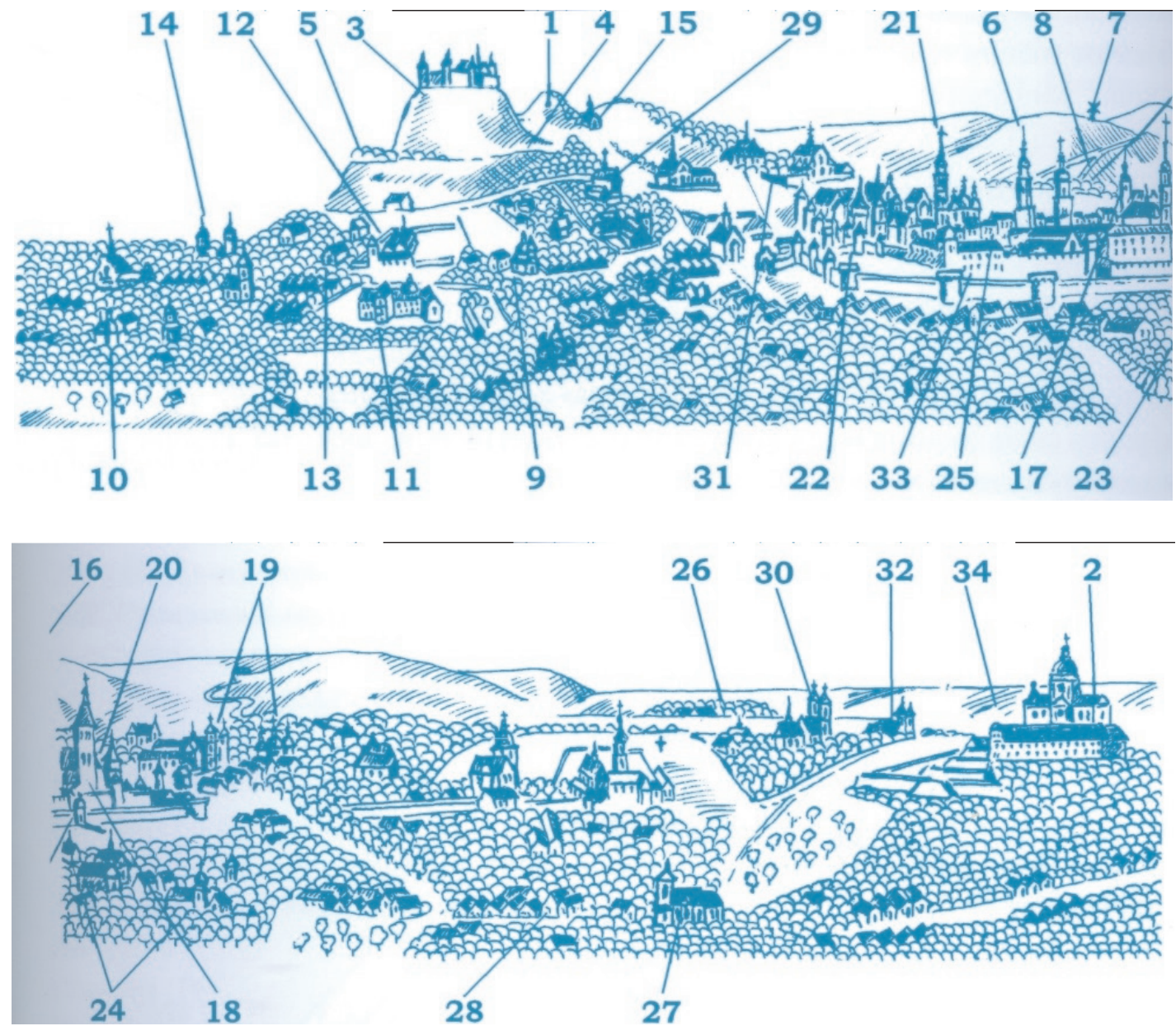

The numbers indicate: 1 - Hora Leva (Lion's Hill), 2 - Sviatoyurska hora (St. George Hill), 3 - Zamkova hora (Castle Hill), 4 - High Castle Outskirts, 5 - Hora Budelnytsia (Budelnytsia Hill), 6 - Chortovi skeli (Chort (Demon) Rocks), 7 - Chortovyi vitriak (Chort (Demon) Windmill), 8 - Lychakiv, 9 - St. Nickolas Church, 10 - Church of the Resurrection, 11 - St. Christ Church, 12 - St. Onuphrius Monastery, 13 - St. Jacob Armenian Church, 14 - Church of the Nativity of the Blessed Virgin, 15 - Church of St. Wojciech, 16 - St. Lawrence Church, 17 - The Bernardine Monastery, 18 - Latin Cathedral, 19 - St. Leonard Church, Epiphany Church, 20 - Golden Rose Synagogue, 21 - Tower of Assumption Church, 22 - Krakiw Gate, 23 - Jesuit Wicket Gate, 24 - St. Stanislaus Church, Church of the Annunciation, 25 - Downtown, 26 - Turkish scones, 27 - St. Anna Church, 28 - Way of the Cross, 29 Church of St. Casimir, 30 - Church of St. Mary Magdalene, 31 - St. Michael Church of the Barefoot Carmelites and Capuchin Church, 32 - St. Lazarus Church, 33 - Low Castle, Fields behind St. George Church.

Fig. 1. Panorama of Lviv in the mid-seventeenth century

Source: Качор, Качор, 2009, р. 134-135.

George Cathedral et al.), even armories (Royal Arsenal). Then - from the early XIX century - Classicism, and from the late - Modernism, especially Constructivism and Secession. All these architectural styles were common-European and in Lviv, they had only certain local modifications.

Thus, for example, since the late XIX century, in Lviv, Ukrainian ("Hutsul") style of construction intensively developed, which had features of constructivism, combining wood frame compositions with interframe space filling with brick, stone, plaster. Adherent of this original style was industrialist Ivan Levynskyi (houses on Ruska St., General Chuprynka St., Mykhailo Kotsiubynskyi St.).
At the same time, after the revolution of 1848, the dominant cultural layer in architecture of Lviv became the so-called Neorenaissance. Therefore, visually Lviv is so similar to Vienna - the capital of the monarchy of that time. With exception, that Vienna is more pompous. An example is the building of Halytskyi Sejm (Diet of Galicia) (now the main building of Ivan Franko National University), of Lviv Polytechnic National University and many others - the so-called revenue houses.

The first industrialization of Lviv started. It spatially coincided with railway, the line of which was built in 1861 from Przemysl to Lviv, and then in 1866 - to Chernivtsi - Odesa and in 1869-1873 - to Brody and 
Ternopil. In Lviv, enterprises of food, textile, wood processing, energy industry and publishing and printing settled. As well as various types of banks (Savings, National (polish Krajowy), Mortgage, "Dnister"Bank), etc. All these, taken all together, led to the formation of centers of industrial production, particularly in Pidzamche area and financial locations on present-day Sichovykh Striltsiv St., Valova St. and V. Hnatiuk St. Lviv becomes the largest in Halytchyna (Galicia) point of political activity (the first political party was organized in 1890 by Ivan Franko, Galician Diet, the bourgeois-democratic revolution of 1848 , and with it the demolition of serfdom in the same year). In this context, exhibition business unfolded (National (Krajowa) Exhibition in 1894 and the start of building of electric transport).

The best preserved elements of historic and cultural heritage are of Austrian period: architectural landmarks, especially buildings in the centeral part of the city: new town hall, houses on Hetmanski Valy St. and Hubernatorski Valy St., on the radial streets (Kopernyka St., P. Doroshenko St., V. Stefanyk St., Shevchenko Prosp., Knyaz Roman St., Lychakivska St. et al.). As well as the cultural sphere buildings - Opera Theatre, Skarbka Theatre (now M. Zankovetska Theatre). And prisons, which were intensively used in the XX century by the Soviet and Nazi occupiers - Bryhidki, Lontskoho, Zamarstynivska prisons. In 1941, thousands of Ukrainian and Polish patriots were murdered there without trial.

The shortest period of historical and cultural heritage is New Polish (1919-1944). It was not characterized by any historical and cultural landmarks. At the beginning of this short period in Lviv, a fratricidal Polish-Ukrainian war broke out. In its commemoration in 30s, "Cemetery Orlont" was built, which now became a center of pilgrimage for Polish tourists (now next to it Ukrainians are building their cemetery as a symbol of reconciliation).

The only, what is remembered now from that time - high-profile killings, including the one of member of the Soviet Consulate Maylov (1933), to bring attention of the world community to the Holodomor in Ukraine. And also, the known pacification in 1930 as infamous suppression of the "recalcitrant".

It is to be recalled that in the interwar period, the batiar subculture blossomed in Lviv. It slowly rose from Lychakiv and Pidzamche hills and hollows (and from the proletarian masses) in the "upper"of Lviv elite. Even a Polish nationwide humorous batiar radio program of comedicians Tońcio and Szczepcio Wesoła Lwowska Fala (Polish for Lviv's Merry Wave) was broadcasted on the local radio from 1933 until 1939.
This period we end with the year of 1944, inasmuch as in 1939-1944, Lviv survived two occupations - Soviet and German, which were not recognized by international politicians. However, on June 30, 1941, the Resumption of the Ukrainian state (Declaration of Ukrainian Independence of June 30, 1941) was proclaimed there, which a few days later was brutally eliminated by the Nazis. In 1941-1943, in Lviv, the Jewish population was massively murdered (A memorial with Menorah symbol was built at the intersection of Chornovil Prospect and railway track).

At the same time, in 1940-1941, the Soviet regime deported to Siberia representatives of Polish nationality, who were civil servants, and in July 1941, the Nazis shot some tens of Lviv universities scientists not only of Polish, but also of Ukrainian and Jewish nationality (now on former Vuletska St. a memorial is built). The Soviet regime dissolved the Shevchenko Scientific Society and destroyed Ukrainian scientists.

Interwar and war Lviv spatially was limited to the area of tram availability. After 1945, and up until 1991, that is more than half a century, it had been the Soviet city period. This period left a great cultural heritage, if all Soviet is not called anti-culture. It is characterized by:

1. Change of the paradigm of spiritual life and activities of the population: russified and sovietized sphere of culture and education; atheisation of faith, liquidation of the Ukrainian Greek Catholic Church (UGCC), destruction of churches - Catholic and UGCC, arrests of priests and Church leaders (in Lviv, there were only a few Moscow-Russian Orthodox churches and two Roman Catholic churches - Latin Cathedral and the church of St. Anthony). Russian culture takes the first place (teaching in vocational schools, high schools is in Russian; just as manuals and textbooks - Russian or translated from Russian).

2. Forced Soviet, that is, the second industrialization of Lviv. Here were imported (in particular due to reparations from Germany and its allies) dozens of industrial enterprises of heavy industry - power lift trucks factory, bus factory, conveyor factory, "Electron" Factory, radio-electronic medical equipment factory, radiotelephone equipment factory (LORTA Lviv State Factory), "Silkhozmash" (agricultural machinery) Factory and several others. And with them, the number of the "Russianspeaking" has grown substantially in Lviv. Intensive construction of large enterprises had several social and economic impacts: an increased number of Russian schools and preschools, as well as employed local residents from suburban ar- 
eas (large-scale circular migration grew to 140 thousand people per day, many of whom settled in dormitories, cellars and residential neighborhoods on the outskirts of the city. The city was intensively russified and ruralized (an indicator of rural culture was vegetable patches and livestock breeding near high-rise buildings and SaturdaySunday migration from the outskirts of the city to relatives in the surrounding villages). With a few exceptions, in enterprises, manual labor dominated (particularly in engineering). The economy of Lviv, primarily engineering (up to $45 \%$ of all employees) and scientific research and project construction sectors were militarized.

3. In the Bolshevism "culture", developing of whistle-blowing, slander, cultivation of malice, envy, etc. were a tradition. Any promotion of a manager on administrative vertical to the higher authorities, party committees or the KGB (Committee for State Security) was not without the help of the mentioned above (the author of the article experienced that all when defending candidate and doctoral thesis). All of that was an expression of spiritual and psychological anti-culture.

4. The area of Lviv increased more than fourfold, and the area of the city council - even more (with local town and rural councils of Bryukhovychi, Rudne, Vynnyk, Sokilnyk, Zymna Voda and others).The city outskirts were connected to the center primarily with trolleybus lines. Semi-ring roads, almost complete ring road were built, radial exits from Lviv were reconstructed and expanded: Stryiskyi, Horodotskyi, Yanivskyi, Zhovkivskyi, Kyivskyi, Vynnykivskyi.

5. By the fact that on this vast area, there were not built any significant buildings that would become dominant in "landscape" (except for the TV tower and antennas for the suppression of foreign radio broadcasts). Moreover, the outskirts were depressingly monotonous, gray, due to the introduction of typical projects to the construction. The main building of Veterinary Institute on Pekarska Str. can be a model of Stalinist style of Sovietisms in construction. Every 15-20 years, the "Diprosmist" Institute (now "Mistoproekt") was preparing and approving "General Plan for the City Development". But any major changes (except the abovementioned) were not observed. Suggested by me the so-called chord (direct) highways (partially on the surface, in tunnels or on overpasses) were not accepted because of their supposedly high cost.

6. In the minds of people, especially young people (teenagers) at the end of the Soviet period, mass culture appeared, which mimicked popular cul- ture of the West after the Russian-Moscow fashion. Unfortunately, it primarily affected students (remember that outskirts were inhabited mainly by village comers with their folk culture). "New Soviet traditions" were cultivated - Komsomol weddings, including international ones; collective leisure in clubs, factory Palaces of Culture, al fresco, in amateur-talent groups, etc. At the same time, church weddings, baptism of children, national traditions, use of the Ukrainian language when on duty were considered undesirable.

7. Growth of the population of the city in three times, of its territory, accelerated industrialization caused a huge overloading of the engineering and transport infrastructure, were worsening environmental situation, required an increase of resources. In particular, there was not enough water, which had to be transported to the city by means of water supply from the distance of $100-150 \mathrm{~km}$.

All these features of the Soviet type of "culture" to some extent crept into a new historical and cultural space of Lviv with certain modifications. That is, they have stabilized in latent form. For example, in the pursuit of wealth and its materialization in the form of pompous, with high tastelessly decorated fencing on the outskirts of the city, in suburban settlements, or even close to the city center.

Ukrainian Lviv has come since the early 90s of the $\mathrm{XX}$ century and extends to the present time, that is a quarter of a century. In historical and cultural terms, it is quite controversial. In culture, there is a number of specific features. In particular, as already noted, it is preservation of certain spiritual and material features of the previous period; acceptation of new trends of Western culture; formation of new features of national culture. In particular:

1) In material sphere - in industry and construction:

a) decline or even complete degradation of certain enterprises and even branches and emergence of the so-called rusty belt. Thus, enterprises of "Avtonavantazhuvach" (power lift trucks factory), Bus and Conveyor Factories, "Poliaron" Factory almost vanished. Territories or equipment of these enterprises are sold or leased;

b) transformation of the sectorial structure of production sphere: highlighting of food (confectionary, bakery, beer) and textile (especially garment) industry largely instead of the former mechanical engineering and chemical;

c) appearance of the sphere of wholesale trade of foreign or Ukrainian goods. Most of the institutions settled in the outskirts of the city in 
the former enterprises of material production sphere;

d) deconcentration (production and territorial) of production sphere and partial concentration of trade ("Metro", "Rukavychka", "Arsen" and others.).

2) In spiritual sphere:

a) priority of freedom of speech and belief. This is evident in the organization of a large number of publishers and media. Full restoration of the UGCC, expansion of other religious denominations, such as Protestant (except Russian Orthodox), construction of places of national memory and memorialization of previously abandoned (fields of Sich Riflemen at Yanivske cemetery, Lviv Orliont in Lychakiv, executed Lviv scientists at Vuletski hills), etc.

b) discommunization and derussification of names of streets, enterprises, esteblisments and city districts were carried out (Leninskyi district in the city center was renamed in Halytskyi (Galician)); monuments and memorials "in honor" of odious figures of Bolshevism (Lenin, Halan) were demolished and monuments to the figures of history and culture of Ukraine (Shevchenko, King Danylo Halytskyi, Hrushevsky et al.) were consecrated.

c) a number of government and diplomatic missions of foreign countries settled in Lviv: Poland, Germany, Belgium and others. These include embassies, general and honorary consulates; representative offices of foreign companies, financial institutions and others.

d) Lviv became a typical European center of science, education and culture. Tourism, financial, information spheres, including IT technology became priorities. At the same time, tourism service sector was reconstructed, particularly food establishments (cafes, restaurants, fast food outlets and so on.) according to different tastes, especially coffee houses - as specifically Lviv brands. IT sector according to the number of employees has reached $10 \%$.

e) in the last ten years began to develop a specific direction in geography - Lviv city studies (Шаблій, 2013).

\section{Geospatial structure of historical and cultural heritage of Lviv}

Geospatial structure of Lviv can be considered in two aspects - horizontal and vertical. They have historically interacted and complement each other at the present time.
The vertical aspect. Three main structural layers (from the bottom upwards) are distinct in it. These are the first, the lowest one, which is under the earth's surface. Call it an archaeological layer. The second layer is overground, represented mainly by artificial structures - streets, roads and other communications that are partly "ingrown" in the first layer, which are occupying its space or even artificially created it (buildings footing, earth containers, pubs, cafes, artificial ditches, water pipes, collectors, etc.).

The remaining part of the overground layer structures and communications: buildings of different functions (residential, public, commercial), transport land lines, green areas and other places of collective use, water flows and reservoirs - ponds, lakes, pools, unused lands, etc. These are the largest in terms of volume spaces that accumulate major historical and cultural values of the city.

The third layer is vertical, which is singled out conditionally. It is represented by the dominant constants of the city - historical and accordingly "decorated" natural objects that together define "urban landscape silhouette" of Lviv.

Let us briefly consider each of them.

The first - archaeological layer - had been forming in Lviv, at least, since the Mesolithic period. Artefacts of Mesolith (12-8 thousand years ago) occur on the High Castle, Kortumova Hill, Chortova (Devil's) Rock and in some other places. Next are the cultures of the Bronze Age, Iron Age and the ones closer to us in terms of time.

It is interesting that Lviv had signs of settlement as early as the first millennium AD. The cultural layer northwards from Opera and Drama Theatres is 10 meters thick. During excavations on its basis, smithing tools and products, leather shoes, household items were found. This shows that the territory of Lviv was cultivated across entire vertical - from the valley of the Poltva to the uplands of the High Castle. The archaeological culture from Halytska Square (South) to Pidzamche area (North) is especially rich (Львів. Комплексний..., 2012). Great concentration is within the former defensive walls, at the intersection of Naukova St. and Kulparkivska St., northwards from the city of Vynnyk and Horodotska St. near the Church of Saints Olha and Elizabeth.

The second vertical layer is the largest in terms of spatial volume and area of its base. It almost entirely covers the earth's surface. However, in some places, especially on steep slopes of the Lviv Hollow, its area is minimal (let us not forget also that these slopes are often covered with artificial plantings parks, public gardens, cemeteries, etc.).

In the second layer, powerful concentration and mosaic of styles and functions of material values are 
observed. Specifically, in the city center, architecture structures such as monuments of history and culture, locations of the city or community centers, historic buildings, events, etc. dominate. Towards the outskirts of the city, "thickness" of this layer increases again due to enlargement of residential buildings up to $9-10$, and sometimes up to 12-14. Outside the area of abutting buildings, in many places (except, of course, fragments of forest-park vegetation), densely verdured, with summerhouse structures built-up, collective gardens and vegetable plots are located.

Finally, the third vertical layer is a set of dominant constants of Lviv, which form its "landscape" silhouette. If you look at this silhouette from any rising ground, and even from not very highly located place, it can not be confused with silhouette of any other city in Ukraine and even European cities.

It highlights the dominant points - of natural (including of partly artificial origin as the cone of the High (astle) and of completely artificial origin. In Lviv, general background contour is created by the High Castle and former Kaiserwald and Kortumova Hill. This contour combines separate towers (usually bell towers) of churches and temples, town hall, TV and others. The main dominants are Television Tower, City Hall Tower, the bell tower of the Assumption Church, the Latin Cathedral tower (that is in the center and in the east). In the west, these are domes of the Cathedral of St. George, upper parts of the Church of Sts. Olha and Elizabeth, of the former church (now Philharmonic Organ Hall) of St. Mary Magdalene.

Particularly interesting are profiles of the third layer, if they are observed along certain street from an elevated point. For example, if one goes to the roof of a high-rise building on Venetsianov Str. (on the Citadel), then along Horodotska Str. from Pryvokzalna Square down to Shevchenko Str. one can see such a profile: sharp and beautiful towers with colonnade of the former church of St. Elizabeth, then - a smooth curve of the named street, created by buildings of almost the same height. Then, approximately in the middle of the profile, domes of St. George Cathedral with gold-plated roofs are aimed in the sky; and at the bottom of the profile - towers of St. Anne Church. A perfect picture.

One traditionally looks at the city center from the viewing point of the High Castle, or from the viewing circle of Union of Lublin Mound. Lviv seems distant in gray-blue haze of car emissions. This subjective picture is completely different, when one goes to the same roof of the high-rise building on Venetsianov St. and looks to the east. It turns out that the named dominant profile of the east of the city is clearly visible against the background of its central part. Images of Lviv in XIV, XVII and XVIII centuries are presented in Fig. 2.

Of course, the vertical structure of Lviv can be not only visualized, but also metrized. It would be best,

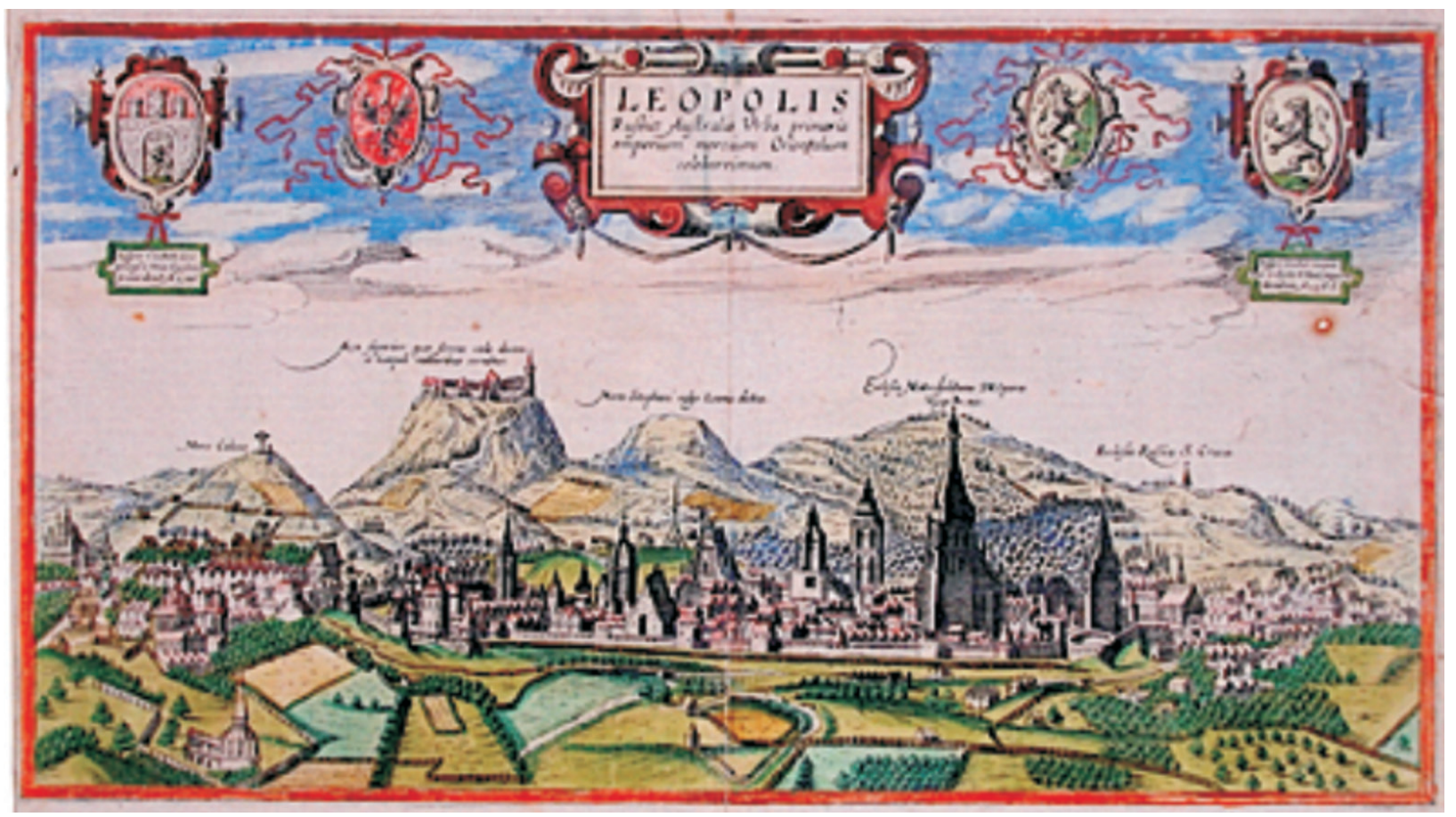

Fig. 2. View of Lviv it the city atlas CIVITATES ORBIS TERRARUM, 1617 (publishers Georg Braun and Franz Hogenberg, draftsman Aurelio Passarotti)

Source: Львів. Комплексний.., 2012. 
if these two approaches were combined. But it is a matter for the future.

The horizontal structure of historical and cultural heritage of Lviv

The horizontal structure of historical and cultural heritage of Lviv was forming during many centuries. Therefore, it is extremely difficult. In addition to historical, natural factors, especially relief, to a large extend, influenced it. Water network of the city and military and defense objectives, set by the city or state heads, mattered a lot.

Let us substantiate the horizontal structure of historical and cultural heritage of the city on the basis of several principles: genetic, functional, value and others. Everything depends on the goals we set ourselves. Thus, the genetic principle involves identifying the place of origin of the city, its territorial development and the process of filling with historical and cultural values. Speaking about Lviv, at first, one should outline the core of its genesis. Most frequently, Pidzamche area with the defensive High Castle is taken as such place. Then the city had been spreading counterclockwise to the sixteenth century, covering the highest castle area from the west and bumping into the valley of Poltva. It was a Gothic Lviv (untill fire of 1527). Later, trade routes to the north, west, south and east went away from it, along which separate districts of the city were forming.

Another principle is administrative. It involves consideration of the existing division of the city into administrative and terretorial units (in our case - raions) while spatial structurization. In Lviv, there are six such raions: Halytskyi (Central), Shevchenkivskyi (Northern), Lychakivskiy (Eastern), Sykhivskiy (Southeastern) Frankivskyi (Southern), Zaliznychnyi (Western). Such division of historical and cultural heritage is somewhat artificial, unnatural to identify the territorial structure of historical and cultural heritage.

Insofar as geospatial organization of the city was very influenced by the natural environment, in determining of horizontal structures of historical and cultural heritage, geomorphological principle can also be used, that is consideration of influence of relief. For Lviv, it is influence of the High Castle and other morphological residual outcrops, hollow of Poltva in its middle part, slightly dipping and steep slopes between the residual outcrops and the river valley.

Finally, the functional principle is based on the fact that certain fragments of the city have a specific function in its life activities. And the very function stems from the value characteristics of individual parts of the city. Therefore, in the spatial organization of Lviv, we distinguish two large structural parts:
1) Historic and Architectural Reserve of World Heritage Site; 2 ) the rest of the city. Each of them still has its internal structure.

UNESCO in 1998. It takes area of 120 ha plus buffer zone of $\sim 3,0$ thousand ha. Together it is $\sim 3120$ ha, which is $20 \%$ of the area of Lviv. In the world, it was listed under number 865 . Reserve stretches from north to south for about $\sim 1.9 \mathrm{~km}$, from west to east in the widest part (in the latitude of the High Castle) - for $\sim 1.6 \mathrm{~km}$, narrowing in the south and especially in the north direction. A separate fragment of the reserve is located on St. George's Hill (Fig. 3).

The southern part of the reserve is the richest in historical and cultural landmarks. It is fixed by the area circled once by defensive walls of the city center. It is limited by Pidvalna Street (in the east), Soborna and Halytska Squares (in the south), Svobody Prospect (in the west) and the beginning of Horodotska and I. Honta Streets (in the north). Here massively are presented not only architectural and artistic landmarks, but also places of significant events, residense and activities of well-known figures. Uncrowned Ukrainian Academy of Sciences Shevchenko Scientific Society, in which Ivan Franko, Mykhailo Hrushevsky, artist Ivan Trush worked, which was visited by Lesia Ukrainka and others, has settled on 24-26, Vynnychenko St., since the late nineteenth century,

Between the beginning of Khmelnytskyi Str. and the High Castle, median territorial part of the reserve stands out, filled with objects and places (traces) of Old Galician cultural heritage (Staryi Rynok (Old Market), churches); in the north - only separete fragments (objects). For example, St. Onuphrius Church.

Outside the reserve of World Heritage Site, we single out several territorial clusters of cultural heritage:

a) protective: Shevchenko Hai Museum of Folk Architecture and Rural Life and Znesinnia Regional Landscape Park (both eastwards from the High Castle). This includes a number of parks of green semi-belt that encircled center of Lviv from other its parts (Kortumova Hill with Yanivivske Cemetery, Ivan Franko Park, Metropolitan Garden, Citadel with B. Khmelnytsky Park of Culture, Stryiskyi Park, Zalizna Voda Park with Snopkivskyi Park and Pohulianka Park with Lychakiv Cemetery. Each of them is characterized by original flora species, and cemeteries - in addition, by compositions of tombs (on the graves of I. Franko, S. Krushelnytska, M.Shashkevych, H. Zapolska et al.);

b) residence and work places of famous writers and artists: streets near Ivan Franko Park, neighbourhoods of Lychakivska St., Professors' Colony area, 


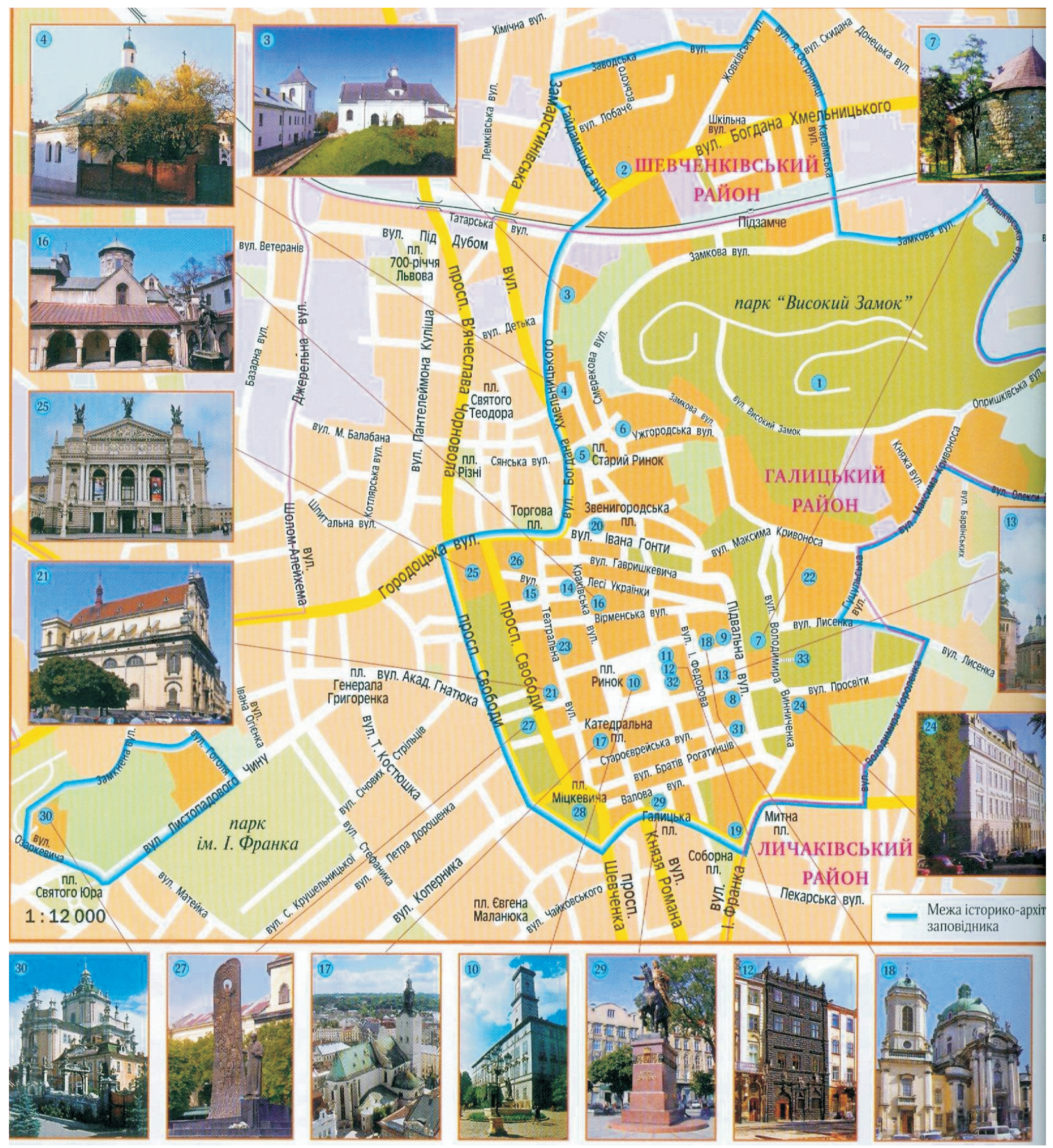

On the map are marked by numbers:

1. Vysokyi Zamok Park, 2. St. Paraskeva Church, 3. St. Onuphrius Monastery, 4. St. Mykolai Church, 5. Staryi Rynok, 6. Ivan Christ Church (The Museum of Ancient Lviv Attractions), 7. Powder Tower, 8. Arsenal (now - The Museum of Ancient Weapon), 9. Royal Arsenal, 10. Rynok Square. City Hall, 11. Bandinelli Palace (now - The Museum of Historical Jewelry), 12. Black Stone House (now - The Museum of History), 13. Dormition Church with Korniakt Tower and Three Prelates Chapel, 14. Church of the Transfiguration, 15. Church of the Benedictines, 16. Armenian Cathedral, 17. Latin Cathedral, 18. Dominican Cathedral, 19. St. Andrew Church, 20. Maria Snizhna Church, 21. Jesuit Church, 22. Church of the Purification, 23. Didushytski palace (now - State Natural Museum), 24. Building of Oblast State Administration and Oblast Rada (Council), 25. Solomiya Krushelnytska State Theatre of Opera and Ballet, 26. Maria Zankovetska Dramatic Theatre, 27. Taras Shevchenko Monument, 28. Adam Mitskevych Monument, 29. Daniel of Halychyna Monument, 30. St. George Cathedral, 31.Ruins of Golden Rose Synagogue, 32. Italian Yard, 33. Carmelite Church (now - Michael the Archangel Church)

Fig. 3. Historical and Architectural Reserve - World Heritage Site, UNESCO

Source: Львів. Комплексний..., 2012. 
Pohulyanka Park (once famous artists colony "Fylypivka");

c) geospatial clusters of production, mainly industrial culture that concentrate enterprises and companies of different specialization and attract numerous employees - people of technical culture. These are old districts of: Pidzamche area (limited by Khmelnitsky Str. and Lypynskyi Str.) and Horodotska Str. near the Main Train Station. Among the new industrial units, there are two to be named: Riasnenskyi and Sykhivskyi.

In the first, "Electron" Factory, producing TVs, dominated. Now it respecialized into production of modern transport vehicles - trams, buses, trolleybuses. In the second, "Poliaron" Factory was the largest, which almost stopped working.

To cultural heritage of Lviv belongs all of its territory, marked by historical events and processes, but not always memorialized. For example, the events of the revolution of 1848 are not reflected in any of the streets (even those on which barricades were erected), not on memorial plaques. The place where Mykhailo Verbytskyi studied at - the author of music of the national and state anthem "The glory and the freedom of Ukraine has not yet died...", i.e., Greek Catholic Seminary on Doroshenko Street, has no memorial sign.

\section{Summary}

Human Geography in Ukraine for the first time begins to study geospatial features of historical and cultural heritage. This issue is at the intersection of several scientific disciplines: general and special. General disciplines, first and foremost, are philosophy that gives fundamental definitions of key terms and concepts: culture, historical and cultural heritage, classification and typology of cultural phenomena and processes. It also includes cultural studies, ie the study of culture as such, and also sociology, psychology and others.

The special disciplines include cultural geography, human geography, geography of services, and even recreational geography. In this interdisciplinary context, geography of historical and cultural heritage should find a place. Especially in those regions and cities that have a long history of development and functioning. These regions and settlements include the West Ukrainian borderlands and especially the city of Lviv.

From all the abovementioned, the following conclusions can be drawn:

1) Historical and cultural heritage is represented by objects of material and (or) spiritual nature, which are transmitted from generation to generation as valuable phenomena from the viewpoint of society (individual social communities).

2) Each object of historical and cultural heritage is characterized by uniqueness against the background of a settlement, region, country or even the world in general (for example, as architectural and temple complex of St. Sophia in Kyiv).

3) Each object of historical and cultural heritage (with few exceptions) undergoes through several historical stages (phases) of its development emergence, establishment and full functioning with transmission of specific structures and functions from the past to the future. As historical and cultural heritage, it can often change its function or lose them. Then its value for society transforms into acquisition of tourism (mainly cognitive features, attributes and functions).

4) For objects of historical and cultural heritage, their being inscribed in natural and social environment is important. That is their functioning in modern landscape of territory (the concept of the landscape here is in the meaning of scenery, view). For example, the cone of the Union of Lublin Mound (1859) in Lviv as a symbol-monument erected to the 300th anniversary of the Union of the Kingdom of Poland and the Grand Duchy of Lithuania, blend seamlessly in residual and hunchbacked landscape around the Lviv Hollow.

5) Each object of spiritual heritage has its material substrate (filling), characterized by a peculiar aspect of cultural heritage, as, for example, printing technology of Ostrih (Ostrog) Bible or production of Ukrainian cinema masterpiece "Shadows of Forgotten Ancestors".

6) Vision of objects of historical and cultural heritage in the context of different-scale of their action and perception is important. Thus, within Ukraine, Hoverla Mountain (2061 m above sea level) with all its tourist and recreational entourage is the highest peak of the national territory. While within Europe - in the Polish Tatras or massifs of the Alps, there arepeaks of much greater height (Mont Blanc is $4809 \mathrm{~m}$ above sea level).

7) Significant in assessment of quality of cultural heritage objects is substantiation of their belonging to a particular historical and cultural type, recording of synchronicity or asynchronicity of their emergence and formation in relation to the main foci of origin. Thus, Baroque architecture replaced the Renaissance in the XVI-XVII century first in Western Europe, when in Eastern Europe, Byzantine culture and architecture (plus painting, mosaic) were still dominating. And to the East, Baroque came only in XVII-XVIII centuries 
and gained national characteristics in the form of the so-called "Cossack" (Ukrainian) temple construction (all temple buildings of Byzantine St. Sophia Cathedral in their perfection were rebuilt accordingly to this Cossack style).

8) In many cases, in urban settlements of Ukraine, including Lviv, in the past, there were certain locations of population of different ethnic and (or) religious groups. Therefore, their historical and cultural heritage against the background of plans of these settlements is often of mosaic nature. Typically, a politically dominant nation occupied central locations in city centers, while ethnic or religious minorities concentrated in "okolnyi hrad" (part of an ancient Rus' city, surrounding kremlin or adjoining it, often fortified by walls), or in areas next to it, or even in rural areas; the latter were often indigenous ethnic groups.

9) On any objects of historical and cultural heritage, time leaves mainly destructive marks on. Therefore, in the research of these objects, it is important to determine the extent of preservation of their initial condition and its conservation. This mostly applies to objects of ancient times, some of which are artifacts.

760-year-old Lviv survived various social and economic, historical and cultural, and state political epochs. Each of them has left its mark on the material and spiritual culture of the city. Therefore, historical and cultural heritage here is extremely rich, varied and complex.

Our first task was to reveal the geographical and temporal features of the formation of this heritage mainly though highlighting phases and periods of entering Lviv consistently into various state systems, ranging from ancient Ukrainian (Ruthenian) and ending today's.

The second task was to substantiate the geospatial organization of historical and cultural heritage of Lviv, as a result of the formation of the historical and cultural centers and their content load and connections between them. Spatial aspect of this organization is considered in two angles - vertical and horizontal. Three layers of the first of them were singled out: underground (archaeological), overground (city proper) and "over-city" (layer of silhouette of city), which largely creates its image.

In the second, horizontal, aspect, two geospatial systems were singled out: 1) Historical and Cultural Preserve of World Heritage Site; 2 ) the rest of the territory. The specificity of each of them was characterized by singling out their main features in general and of individual subsystems.

In UNESCO Reserve, the peculiarities of its southern (now main), middle and northern parts were covered. On the rest of the territory, common features of geospatial organization of material (particularly industrial) and spiritual cultures were highlighted.

\section{References}

Bałaban M., 1909, Dzielnica żydowska, jej dzieje i zabytki, Nakł. Towarzystwa Miłośników Przeszłości Lwowa, Lwów.

Brown K., 2009, A biography of no place: from ethnic borderland to Soviet heartland. Harvard University Press, Cambridge.

Charewiczowa L., 1925, Handel średniowiecznego Lwowa, Zakład Narodowy imienia Ossolińskich, Lwów.

Czołowski A., 1896, Lwów za ruskich czasów, Wyd. Aleksander Czołowski, Lwów.

Harvey D., 1979, Monument and Myth, Annals of the Association of American Geographers, 69(3), 362-381.

Harvey D., 2015, Heritage and scale: Settings, boundaries, and relations, International Journal of Heritage Studies, 21(6), 57-59.

Hobsbawm E., Ranger T., 2001, The Invention of Tradition, Cambridge University Press, Cambridge.

Janush B., 1918, Zabytki przedhistoryczne Galicyi Wschodniej, Towarzystwo dla Popierania Nauki Polskiej, Lwów.

Knudsen D., Greer C.E., 2008, National Park Thy: Symbolic Landscape, Wild Land and Heritage Tourism, Journal of Heritage Tourism, 3(1), 18-35.

Lowenthal D., 2005, Natural and Cultural Heritage, International Journal of Heritage Studies, 11(1), 81-92.

Łoziński W., 1901, Stuka Iwowska XVI-XVII wieku: architektura i rzeźba, nakł. Księgarni H. Altenberga, Lwów.

The National Geographic desk reference: a geographical reference with hundreds of photographs, maps, charts and graphs, 1999, A Stonesong Press Book, Washington.

Грушевський М., 1991, На порозі нової України, Знання, Київ.

Груневег М., 1980, Опис Львова, Жовтень, 10, 109-114.

Долинська М., 2006, Icторична топографрія Львова XIV-XIX cm., Видавництво Національного університету “Львівська політехніка", Львів.

Запаско Я., Мацюк О., Стасенко В., 2000, Початки українського друкарства, Центр Європи, Львів.

Зиморович Б., 2002, Потрійний Львів: Leopolis Triplex, Центр Європи, Львів.

Ісаєвич Я.Д. (ed.), 2005, Історія Львова, Афіша, Львів.

Капраль М., 2003, Начіональні громади Львова XVI-XVIII cm., Літературна агенція “Піраміда, Львів.

Качор І.В., Качор Л.О., 2009, Марево давнього Львова, Апріорі, Львів.

Культурологія: енциклопедичний словник, 2013, ЛНУ імені Івана Франка, Львів.

Львів. Комплексний атлас, 2012, ДНВП “Картографія", Київ.

Маланюк $\epsilon$, 1992, Нарис історії української культури, АТ "Обереги", Львів.

Мельник І., 2008, Львівські вуличі: кам'яниці, мури, закамарки, передмістя та інші особливості королівського столичного міста Галичини, Центр Європи, Львів. 
Нееф Э., 1974, Теоретические основы ландшафтоведения, Прогресс, Москва.

Паславський І., 2010, Хто і коли заснував місто Львів, Укр. технології, Львів.

Ровенчак I.І., 2008, Географія культури: проблеми теорії, методології та методики дослідження, Видавничий центр ЛНУ ім. Івана Франка, Львів.

Рудницький С.Л., 1905, Нинішня географія, Руське Товариство педагогічне, Львів.

Степанів О., 1943, Сучасний Львів, Українське видавництво, Краків-Львів.

Шаблій O.І., 1993, Академік Степан Рудницький: фундатор української географії, Видавничий центр ЛНУ ім. Івана Франка, Львів.

Шаблій О., 2013, Львовознавство: підходи, аспекти, проблеми, Історія української географії, 27, 8-14. 